\title{
Article \\ Applying International Guidelines on Historic Building's Retrofit in New Zealand: A Critical Context View
}

\author{
Rachel Paschoalin*(D) and Nigel Isaacs (D) \\ School of Architecture, Victoria University of Wellington, Wellington 6011, New Zealand; nigel.isaacs@vuw.ac.nz \\ * Correspondence: rachel.paschoalin@vuw.ac.nz
}

\begin{abstract}
Interest in the energy retrofit of historic buildings reflects the current drive to reduce greenhouse gas (GHG) emissions. New Zealand (NZ), unlike Europe and USA, has no country-specific guidelines considering heritage conservation, energy efficiency, reduced carbon emissions and cost. The paper explores benefits to NZ from a policy and practice perspective from such procedures. The adoption of tailored retrofit guidelines would contribute to the national goal of reduced GHG emissions by 2050. The case study investigates the relevance and challenges of assessments such as heritage impact, life-cycle carbon assessment and life-cycle costing for historic building renovations. Through interviews with a range of experts, the results for hypothetical retrofits of a heritage building are evaluated. The interviews reveal how possible trade-offs among different assessment criteria (e.g., energy, cost, carbon footprint and heritage impact) are considered by different specialist groups, as well as exploring the benefits and barriers, and providing recommendations for future renovation guidance. The main findings highlight the importance of a life-cycle perspective and of conservation plans for heritage assessment. The experts all agreed that from a conservation perspective, there was no one energy retrofit solution that fits all building types and cases.
\end{abstract}

check for

updates

Citation: Paschoalin, R.; Isaacs, N. Applying International Guidelines on Historic Building's Retrofit in New Zealand: A Critical Context View. Heritage 2021, 4, 3697-3711. https:/ / doi.org/10.3390/heritage4040203

Academic Editor: Tor Broström

Received: 2 October 2021

Accepted: 15 October 2021

Published: 19 October 202

Publisher's Note: MDPI stays neutral with regard to jurisdictional claims in published maps and institutional affiliations.

Copyright: (c) 2021 by the authors. Licensee MDPI, Basel, Switzerland. This article is an open access article distributed under the terms and conditions of the Creative Commons Attribution (CC BY) license (https:/ / creativecommons.org/licenses/by/ $4.0 /)$.
Keywords: historic buildings; life-cycle analysis; energy retrofit; conservation; carbon emissions

\section{Introduction}

The building sector globally is responsible for 36\% of energy use and at least 30\% of greenhouse gas (GHG) emissions per year [1]; however, if GHG emissions are not reduced climatic impacts are likely to be irreversible [2]. There are opportunities from sensible retrofits of historic and heritage buildings to reduce GHG emissions and energy consumption [3-8]. The Paris Agreement $\mathrm{CO}_{2}$ reduction targets have contributed to the development of new government policies as well as voluntary standards such as the European EN 16883:2017 and American ASHRAE 34P:2019 guidelines for renovation of historic buildings $[8,9]$, and the emergence of European and international group research tasks on historic building energy retrofits including EFFESUS, RIBuild, 3encult and IEA Task $59[10,11]$.

Despite many conservation challenges arising while energy renovating historic buildings, at the international level, ICOMOS has recognized the importance of cultural heritage supporting sustainable development of cities [3,12]. Many countries have developed guidance material on how to insulate walls, windows or even adding photovoltaic (PV) panels to heritage and historic buildings [13-15]. The topic of historic retrofit has been widely investigated in the last decade from both technical and conservation sides; however there is still limited discussion about the heritage significance assessment and its influence on the decision-making [11,16], while from a practice perspective energy retrofits are still limited by regulatory, social and technical barriers [17].

Compared to Europe and USA, New Zealand (NZ) discussions on energy retrofits of historic buildings are at the initial steps. This is despite there being many old and vacant historic buildings in town centers, many with a degree of heritage value, in need of improvements to be fit for purpose [18]. One of the reasons energy retrofits are not 
yet in the forefront of discussion is the concern with meeting mandatory strengthening requirements attributable to high seismic activity [19]. NZ has a 2050 legal target for reducing GHG emissions to 50\% of the 1990 levels [20], being implemented through a zerocarbon policy [21]. This, at the time of writing, focuses exclusively on new construction, resulting in no country-specific guidelines for historic building retrofits.

Most existing historic buildings remain untouched by energy upgrades due to the lack of required compliance for energy efficiency as well as exemptions by 'if practicable' clauses in the mandatory New Zealand Building Code (NZBC) [22,23]. This coupled with the perception that old buildings are cold, damp and leaky [24], and their possible earthquakeprone status may pose demolition risks for many neglected historic buildings [25]. In addition, the country is facing a housing crisis due to many years of underinvestment in house construction coupled with population growth leading to pressure for higher-density inner city and suburban developments, hence an increasing risk of historic houses demolition [26]. Currently in the capital city Wellington, there are consultations as to in which city areas historic and heritage buildings will be protected or not by the proposed 'Draft Spatial Plan for Growth' which will rule where new developments can occur [27]. This is raising concerns of valued heritage and character areas being threatened by demolition [26,28].

On the other hand, it is argued that the sensible retrofit of historic buildings allows for improvements and adaptations for future needs, contributes to more healthy indoor environments, reduces environmental impacts while protecting the historic values, fabric and embedded carbon of these houses from demolition [5,8,29].

Given the current scenario, there is a gap in policy and practice regarding retrofit of historic buildings when compared internationally [30], thus NZ could benefit from appropriate tailored guidelines. However, there is also a gap in NZ research dealing with technical and conservation aspects of historic buildings retrofit, being limited to a few research publications and practice case examples that not fully address the challenges of historic preservation [31,32] or consider a holistic deep retrofit with different variables and interactions among different stakeholders $[6,8,11,33]$.

The purpose of this paper, based on a theoretical case study, is to explore the use of the international guidelines for historic retrofit, and whether NZ could benefit from a policy and practice perspective from adopting similar procedures. Additionally, the paper reflects on the appropriateness, challenges and gaps of methods for assessing different criteria. Finally, it discusses how heritage significance assessment is crucial in decision-making. The paper explores awareness of the contribution of retrofit policies and practice for protecting historic buildings while reflecting on international guidelines rationale.

In this paper the term "historic building" includes both officially listed and protected buildings as well as older buildings without an official designation. The terms "retrofit", "renovation" and "refurbishment" are considered synonyms, referring to fabric and service upgrades.

\section{Existing Guidelines for Historic Buildings' Renovation}

In the past decade, three important voluntary standard guidelines have been developed to establish generic procedures, assessment criteria and recommend methods for the energy renovation of historic buildings, including those statutorily protected $[8,17]$. Chronologically the first was the AiCARR (Italian Society of Refrigerating) 2014 guidelines proposing an interdisciplinary approach to contribute to the European 2050 energy use targets and GHG emissions reductions [34]. It introduced a procedure for auditing historic building energy use before and after retrofitting. The assessment criteria was mainly focused on comparison of energy and heritage significance analysis [34]. AirCARR also includes topics for renewable energy generation, hygrothermal analysis and tailored simulation considering users' behavior [35].

In 2017, following publication of the Italian document, the European Committee for Standardization developed and implemented EN 16883:2017 Guidelines for improving the energy performance of historic buildings [8]. This document, similar to previous guide- 
lines, describes a procedure to be used by interdisciplinary stakeholders while renovating historic buildings. It also advocates on the broader context of sustainable management of buildings, including environmental (material and energy audits), economic (market value, revenues and long-term costs), social (aesthetic and social imprint) and cultural (heritage significance retained for future generations) aspects [8]. The guidelines cover: firstly, the need for a historic building survey and pre-assessments before any renovation solutions are proposed; secondly, a list of assessment categories and criteria for evaluating the proposed solutions; thirdly, an assessment scale in terms of risks and benefits aiding decision-making; and finally, for some assessment criteria, the corresponding international and European Standards for appropriate methods [8].

The next guidelines document was the American ASHRAE Energy Guideline 34-2019 for historic buildings [9]. This is similar to the two previous in the sense of providing procedures for a best-balanced renovation design. However, compared to the European Standard, it has more details about the existing building envelope diagnosis including recommendations for hygrothermal analysis of heat, air and moisture flows; measurements of indoor temperature and humidity; use of a blower door test and infrared thermography. Preliminary energy analysis, thermal comfort analysis and air quality monitoring are recommended to calibrate a tailored energy model. Finally, the procedure also requires results be compared regarding energy savings against potential impacts on the historic building [9].

Despite all these guidelines advocating multiple-criteria assessment, they all have a strong focus on two main criteria: energy savings versus heritage significance. Other criteria and recommended assessment methods, such as carbon savings and the life-cycle carbon analysis, do not have the same attention. EN 16883:2017 is the most complete framework amongst the three guidelines as it includes aspects such as economic viability, impact on the outdoor environment, and GHG emissions [8]. However, a more in-depth approach and a clear recommendation for life-cycle analysis is not often clear from all three guidelines.

The energy upgrade of a historic building will reflect on less operational energy, hence less on operational carbon emissions. However, the materials' embodied energy and carbon, replacement and maintenance within the life cycle need also to be assessed.

This paper explores the impact on the decision-making processes of heritage conservation specialists through provision of simulation model results of the energy, life cycle cost and life cycle carbon for a range of renovation options. Ten professionals from public and private organizations were interviewed, and their responses analyzed. The paper concludes with a discussion of the value of such an approach to historic renovation.

\section{Authenticity and the Heritage Significance Assessment}

Heritage assessment, despite its stated importance in guidelines, research programs [10] and its widely heritage practice application, is not seen as detailed in published material on historic retrofits [11,16]. Often energy retrofit research does not detail how the heritage assessment or historic values influenced the final decision-making. It is often stated that due to legal protection the exterior appearance of the building cannot be altered, thus only interior solutions are considered [5]. However, authenticity and heritage assessment should not be limited to only the exterior material and visual appearance.

The concepts of authenticity and cultural significance have been treated and defined in different ways since the first ICOMOS Conservation Charters which were strongly based on European ideals of values associated with build heritage [36,37]. According to Araoz [36] the modern heritage movement was created by the focus of Eurocentric visions and theories on the material existence of significant places. The Venice Charter of 1964, one of the first ICOMOS documents, advocated the conservation of physical components where historic and aesthetic values were attributed, but that only trained professionals were able to fully understand the significance of historic places [38]. 
The Venice Charter paradigms were later challenged and reconsidered, especially regarding cultural significance and their appropriation by different communities [36]. Aspects that changed through time included the role of communities and the understanding of the significance of a heritage place. Two ICOMOS Charters, the 1979 Burra Charter (latest revisions 2013), and the 1994 Nara Document on Authenticity played an important role consolidating these new paradigms. The Burra Charter enlarged the list of significant values including "places of cultural significance reflect the diversity of our communities", and acknowledging that values (including social and spiritual) can be seen differently amongst individuals and groups, [39]. The Nara document marked a shift from the Eurocentric belief in absolutes of tangible physical attributes towards the acceptance of relative, contextual and intangible values, and authenticity [37,40].

Following the concept of authenticity in the 1994 Nara document, the 2005 World Heritage Operational Guidelines for international heritage nominations were also altered. The authenticity approach was further broadened in 2005 from design, materials, workmanship and setting parameters to form, substance, use, functions, traditions, techniques, location, language, spirit and feeling parameters [37,41], emphasizing differences in the cultural context. According to Jokilehto [41] authenticity refers to being truthful and significance is built up in dialogue with society, therefore, the authenticity needs to be verified not only in the construction itself but also in the continuity of community tradition, spirit and feeling. However, communities are constantly changing so cultural significance is also dynamic, therefore the focus should be on managing change instead of preventing it [36].

In New Zealand, the 2010 NZ Charter and 2013 Burra Charter are the main reference documents for assessing cultural significance. Therefore, cultural significance and authenticity are based on a set of values including not only aesthetic and historic as the 1964 Venice Charter, but also social, scientific and spiritual values according to the cultural context [39,42], comprising not only tangible but also intangible values attributed to the place. The Burra Charter [39] recommends that through community and stakeholder engagement a conservation management plan (CMP), containing the assessment of significance and cultural values [43], should be developed as part of a conservation policy. Beyond any heritage significance statement incorporated into the CMP, it should also include obligations, future needs, risks, and constraints for managing changes. Conservation plans and cultural significance assessment need to be periodically reviewed due in light of the dynamic character of heritage [39]. However, this is not always followed in practice, as conservation plans are seldom reviewed after completion [44].

\section{Role of Conservation Plans}

Often the exclusive focus on material fabric authenticity remains embedded in institutional practice, legislation, and training [36], nevertheless the CMP has an important role as it can aid decision-making, e.g., supporting sensitive fabric changes, without diminishing overall significance. Burra Charter, Article 27 [39] states that for any proposed changes one way to manage cultural significance impacts is to assess them against the statement of significance and values. It is clear that when improving the historic building's performance or adapting for different uses, the CMP is essential for guiding heritage impact assessments to manage changes and avoid detrimental actions.

Internationally organizations such as Historic England recognize that changes to the historic buildings, including energy upgrades, is inevitable therefore managing change is critical [44]. Contemporary community acceptance of a broader range of values, such as sustainability as a cultural value [45], and the recognition that urban heritage is a dynamic resource can enable more sensitive and flexible approaches [36]. According to the Nara Charter of Authenticity and the World Heritage Operational guidelines for testing authenticity, parameters such as use, traditions, techniques, location, language, spirit and feeling gain relevance in the decision-making.

Assessing significance is the most important process and should influence everything else, meaning practical decisions are simply based on the values stated at the CMP. Values 
are not quantitative, which makes simplifications difficult to scoring systems [44]. Therefore, in the first stages on the renovation process the understanding of the asset's overall significance, the significance of elements and the impacts of change may come from the CMP. For example, the Wellington City Council (NZ) heritage policy requires conservation plans only for buildings subject to heritage orders, which are protected by the district plan provisions, but recommends that all listed heritage buildings should have one [43]. Therefore, not all historic buildings have a CMP identifying issues of significance.

Even when if a CMP is developed, this does not guarantee its effective use. Worthing and Organ [44] observed that often CMPs have limited engagement with broader global trends such as greater awareness on carbon emissions, and are not practical working documents, as they lack key performance indicators (KPIs) or mechanisms for effective monitoring. They also noticed a greater importance is given to tangible elements over intangible, because they are more obvious and professionals have more training with physical elements. This can be corrected through updated CMPs.

Despite such desired CMP improvements, they remain the most valuable documents for understanding heritage significance and management of changes. Provided CMPs contain both long-and short term actions [46], they are the most suitable document for initiating conversations about the renovation process, as well as aiding decision-making.

\section{Methodology}

The first part of this study identified through an international and national literature reviews the following topics: a lack of NZ tailored energy retrofit guidelines; limited research addressing specific conservation challenges; and the lack of a role for conservation plans and heritage values in energy retrofits. Given the limited energy retrofit practice [30] and a lack of NZ guidelines, this research used a theoretical case study using EN 16883:2017. The research focused on important assessment criteria (user comfort, carbon and cost analysis) in order to understand their effect in the decision-making process.

This theoretical retrofit study explored a series of wall and window insulation options which would improve indoor quality, lengthen the building's useful life, reduce GHG emissions, while protecting the heritage significance. Following the European guidelines to use of different stakeholders, this study also included interviews with a group of NZ stakeholder experts involved in energy renovations. Qualitative interviews investigated the practicality of adopting tailored guidelines, the differences between different professionals ${ }^{\prime}$ points of view, the challenges which arise from these, and what needs to be dealt before implementing guidelines in the country. The group of stakeholders' experts was comprised of retrofit practitioners, such as architects, conservation professionals, engineers, assets managers and advisors from both public and private sector $[8,11,33]$.

The next sections introduce the case study and provide a summary analysis of different assessments from energy, thermal, carbon and cost perspectives, which were presented as part of the stakeholder interviews. The interview findings are then discussed. The novelty of this paper pertains to the practicality of adopting guidelines for energy retrofit, as well as promoting awareness and discussion of benefits and challenges for both technical and conservation issues. These contribute insights for policy-making support.

\section{Case Study Description}

The Former Custodian's Residence, a 1901 typical, fairly plain villa (Figure 1) is located in the suburb of Khandallah, Wellington, NZ. The Residence represents a typical historic NZ house construction of "light timber frame, timber wallboard cladding, corrugated iron roofed free-standing house developed with a suspended wooden floor" [47]. These timber-framed city houses reference to the northern English vernacular and symmetrical rectangular plan [48]. Despite some changes over time, this villa has moderate authenticity, retaining the original external rusticated weatherboards and with a mixture of original large double-hung windows and modern casements. The house has been under Wellington City Council ownership since 1919, when the first custodian of the Khandallah Domain 
occupied the house with his family. Until the 1990s, it was used as the custodian's residence and was later tenanted by council staff [49]. Since 2018, the house has been unoccupied and the Council searching for new tenants [50].

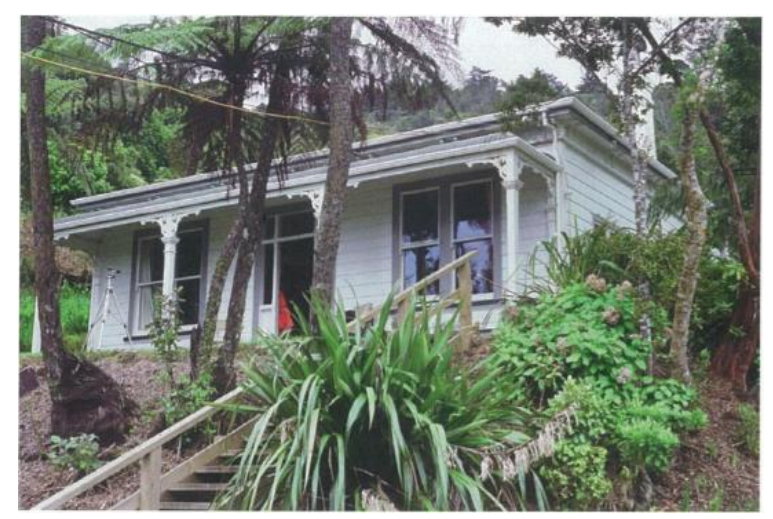

Figure 1. Former Custodian Residence. Source: [49].

The house listed in the Wellington District Plan, has local heritage significance within the Khandallah suburb, and it is one of oldest remaining Council custodial houses. It is located on an elevated site at the end of Clark Street strongly contributing to the setting. The conservation plan [49] describes the exterior fabric, including the front verandah, as original but the modern casements on east and west facades reduces the overall exterior authenticity. The interior was extensively altered and it is no longer fabric authentic. As with many timber-frame houses built prior to 1970s insulation requirements, has dampness issues on its west elevation which is enclosed by native bush [49]. This aligns to the national perception that historic houses are cold and damp [24], having issues with mold growth, and occupant asthma and other respiratory diseases [51]. To reduce dampness, and improve indoor thermal comfort, in 2018, the Council started to renovate the house, but only a few measures were implemented, including roof insulation.

Therefore, this study was designed to explore the energy and environmental benefits of thermal comfort, carbon and cost savings of a deep retrofit including insulation and airtightness [6] and the heritage costs. Enhancing the building envelope thermal performance would benefit the occupants' thermal comfort and health [5,52], as well as reducing heat losses and reduce heating energy consumption.

The European and American guidelines on energy renovation of historic buildings, give the first stages in the process as a building assessment and survey; defining the main goals followed by assessments of compatible solutions $[8,9,17]$. This case study was prepared following the same process. Primary, historic documents and technical reports provided by the Wellington City Council were consulted to understand the building's history and the current physical condition. These showed that in 2018 polyester blanket insulation was added to the ceiling, an HRV pressure ventilation system, a heat pump was added in the living room and new carpets were installed in bedrooms and living room.

The expected goals, considering the building history and use, were to improve indoor thermal comfort, reduce energy use and carbon emissions, reduce dampness and enable a healthier indoor environment all while protecting the historic character. Given the holistic assessment categories presented in EN 16883:2017 [8], thermal comfort, energy consumption, carbon savings and costs were the main criteria used for assessing the proposed retrofit solutions. Heritage impact assessment was also crucial, but assessment was carried by experts through the interviews.

\section{Summary of Analysis}

The research consisted of a modelling, assessment and analysis by a two-part mixed method: firstly, quantitative assessments of different energy efficiency options and secondly, qualitative interviews with experts based on the first stage results. A booklet (Figure 2) was 
prepared using the results from the first stage and presented to interviewees. It comprised: the project outline; a summary of the heritage significance stated in the CMP [49]; a series of images of the potential visual appearance of the different retrofit options and the graphed results from the assessment criteria (e.g., comfort, life-cycle carbon-LCCA and life-cycle cost-LCC).
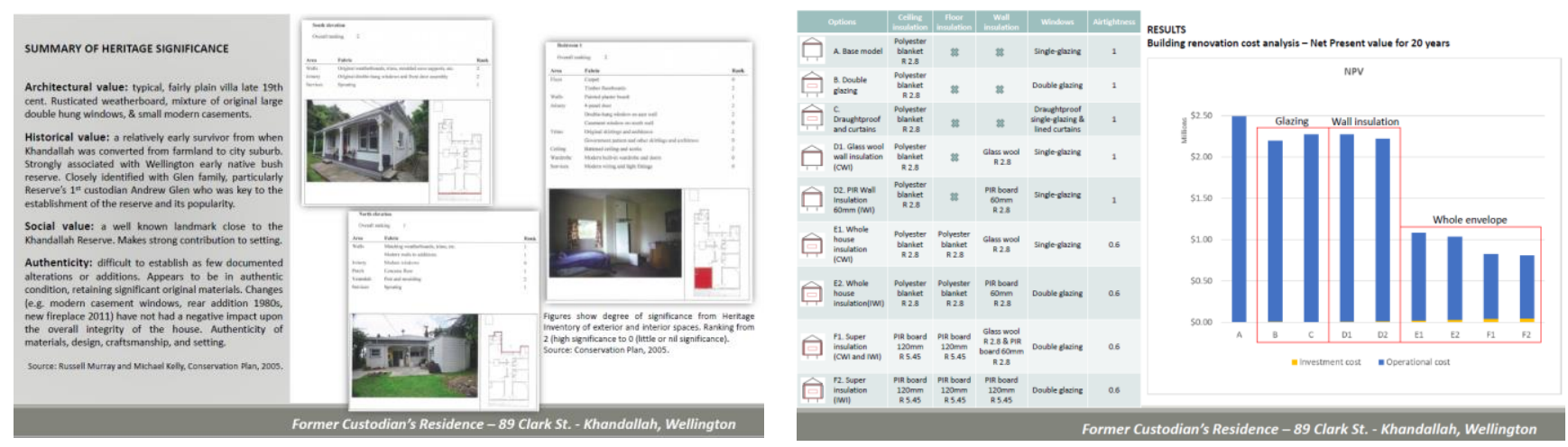

Figure 2. Examples of booklet pages shown to interviewees.

A building survey took detailed physical, construction and materials measurements which were translated to a baseline EnergyPlus model used for energy, carbon and cost life-cycle analysis. Model information and assumptions are available on request.

The base model and each retrofit measure was assessed by the annual hours of comfort using the adaptive model of comfort [53]; heating energy expressed as a fraction of the baseline model (\%); $\mathrm{kg}$ of $\mathrm{CO}_{2}$ equivalent (LCCA) produced by the heating system; and net present value in NZD (LCC). It is acknowledged that important categories and criteria were not included in this investigation due to their complexity and specific analysis requirements (e.g., salt risks, structural risks, hygrothermal analysis, etc.). However, their relevance was explored during the interviews.

The house base model has uninsulated timber-frame cavity walls, suspended timber floor, single-glazed wooden frame windows, insulated ceiling and a corrugated iron, pitched timber-frame roof. The proposed renovation scenarios started with upgrading only windows, secondly upgrading only walls and thirdly upgrading the whole envelope (wall, floor, roof and windows) and reducing airtightness. The scenarios also vary from insulation product R-value of $2.8 \mathrm{~m}^{2} . \mathrm{K} / \mathrm{W}$ to $5.45 \mathrm{~m}^{2}$. K/W. Their envelope composition from external to internal layers plus components $\mathrm{R}$-value $\left(\mathrm{m}^{2} . \mathrm{K} / \mathrm{W}\right)$ are given in Table 1 , while the descriptions are given below:
A. Base model;
B. Retrofitted double-glazing;
C. Draughtproofing windows and adding lined curtains;
D. Fiberglass cavity wall insulation (CWI);
E. PIR board internal wall insulation (IWI);
F. Whole house insulation with CWI (R2.8 product);
G. Whole house insulation with IWI (R2.8 product);
H. Whole house super insulation with both CWI and IWI (R5.45 product); and
I. Whole house super insulation with IWI (R5.45 product).

The insulation materials proposed for walls include rigid insulation boards directly fixed to the walls (e.g., PIR-board) and non-rigid insulation materials (e.g., fiberglass) for cavities as is usual practice in NZ timber-frame houses. However, adding internal insulation to the existing wall, especially vapor-tight insulation systems, requires caution so to avoid possible water-vapor penetration and potential condensation [5]. For this reason, existing guidelines recommend the hygrothermal analysis of all components to assure existing fabric compatibility, and to avoid mold growth and material decay $[8,9]$. 
Due to technical limitations, hygrothermal analysis was not part of this simplified study but it is noted that moisture assessments are an important part of a holistic deep retrofit.

Table 1. Building envelope composition from outside to inside layers for all different scenarios.

\begin{tabular}{|c|c|c|c|c|}
\hline Scenarios & Roof & Floor & Wall & Windows \\
\hline A & $\begin{array}{c}\text { Corrugated iron sheet }+ \\
140 \text { mm ceiling joists } \\
\text { and dwangs }+ \\
\text { Ventilated roof space + } \\
100 \text { mm polyester } \\
\text { blanket insulation }+ \\
10 \text { mm gypsum } \\
\text { plasterboard (R2.8) }\end{array}$ & $\begin{array}{c}\text { Ground }+ \\
\text { sub-floor ventilated } \\
\text { space }+ \\
140 \text { mm floor joists } \\
+20 \text { mm particleboard } \\
\text { (R0.31) }\end{array}$ & $\begin{array}{c}\text { Rusticated weatherboard }+ \\
90 \mathrm{~mm} \text { timber frame cavity }+ \\
10 \mathrm{~mm} \text { gypsum plasterboard (R0.4) }\end{array}$ & Single-glazing (R0.19) \\
\hline B & As for $\mathrm{A}$ & As for $\mathrm{A}$ & As for $\mathrm{A}$ & $\begin{array}{l}\text { Double glazing } \\
\text { Low-E (R0.5) }\end{array}$ \\
\hline $\mathrm{C}$ & As for $\mathrm{A}$ & As for $\mathrm{A}$ & As for $\mathrm{A}$ & $\begin{array}{l}\text { Single glazing and } \\
\text { lined curtains (R0.33) }\end{array}$ \\
\hline $\mathrm{D}$ & As for $\mathrm{A}$ & As for $\mathrm{A}$ & $\begin{array}{l}90 \mathrm{~mm} \text { fiberglass insulation added } \\
\text { in wall cavity (R2.2) }\end{array}$ & As for $\mathrm{A}$ \\
\hline $\mathrm{E}$ & As for $A$ & As for $\mathrm{A}$ & $\begin{array}{l}60 \mathrm{~mm} \text { PIR insulation board }+10 \mathrm{~mm} \\
\text { gypsum plasterboard on top of } \\
\text { existing wall (as for A) (R3.2) }\end{array}$ & As for $\mathrm{A}$ \\
\hline $\mathrm{F}$ & As for $\mathrm{A}$ & $\begin{array}{l}100 \mathrm{~mm} \text { polyester blanket } \\
\text { added in between the } \\
\text { floor joists (R2.75) }\end{array}$ & As for $D$ & As for B \\
\hline G & As for $\mathrm{A}$ & As for $F$ & As for $\mathrm{E}$ & As for B \\
\hline $\mathrm{H}$ & $\begin{array}{l}100 \mathrm{~mm} \text { polyester } \\
\text { blanket insulation } \\
\text { Replaced by } 120 \mathrm{~mm} \\
\text { PIR insulation board } \\
\text { (R4.8) }\end{array}$ & $\begin{array}{l}120 \mathrm{~mm} \text { PIR insulation } \\
\text { board } \\
\text { added in between the } \\
\text { floor joists } \\
\text { (R4.4) }\end{array}$ & $\begin{array}{c}90 \mathrm{~mm} \text { fiberglass insulation added } \\
\text { in wall cavity }+ \\
60 \mathrm{~mm} \text { PIR insulation board }+ \\
10 \mathrm{~mm} \text { gypsum plasterboard on top } \\
\text { of existing wall (as for A) (R5.0) }\end{array}$ & As for B \\
\hline I & As for $\mathrm{H}$ & As for $\mathrm{H}$ & $\begin{array}{c}120 \mathrm{~mm} \text { PIR insulation board + } \\
10 \text { mm gypsum plasterboard on top } \\
\text { of existing wall (as for A) (R5.8) }\end{array}$ & As for B \\
\hline
\end{tabular}

The results from different variations in Table 1 were grouped and graphed for the interviewees. Firstly, a graph of the results from the adaptive thermal comfort analysis (Figure 3), labelled according to the percentage of hours considered cold $\left(\leq 18^{\circ} \mathrm{C}\right)$, comfortable $\left(18{ }^{\circ} \mathrm{C}<\right.$ and $\left.>26^{\circ} \mathrm{C}\right)$ and hot $\left(\geq 26^{\circ} \mathrm{C}\right)$, for the base model (A) and retrofit scenarios (B-I) were presented. Mean radiant temperature and mean air temperature were outputted from the model, as surface radiation temperatures contribute to an uncomfortable condition with the more homogeneous the temperatures (air and radiant) the greater the sensation of comfort [54]. Figure 3 illustrates that the more insulated the envelope (walls, floor, ceiling and windows) the more comfort hours during the year compared to the baseline model (A). From F to I, the whole-house insulation scenarios with reduced airtightness, there is an average $20 \%$ difference compared to other single measure scenarios (e.g., only walls or windows). 


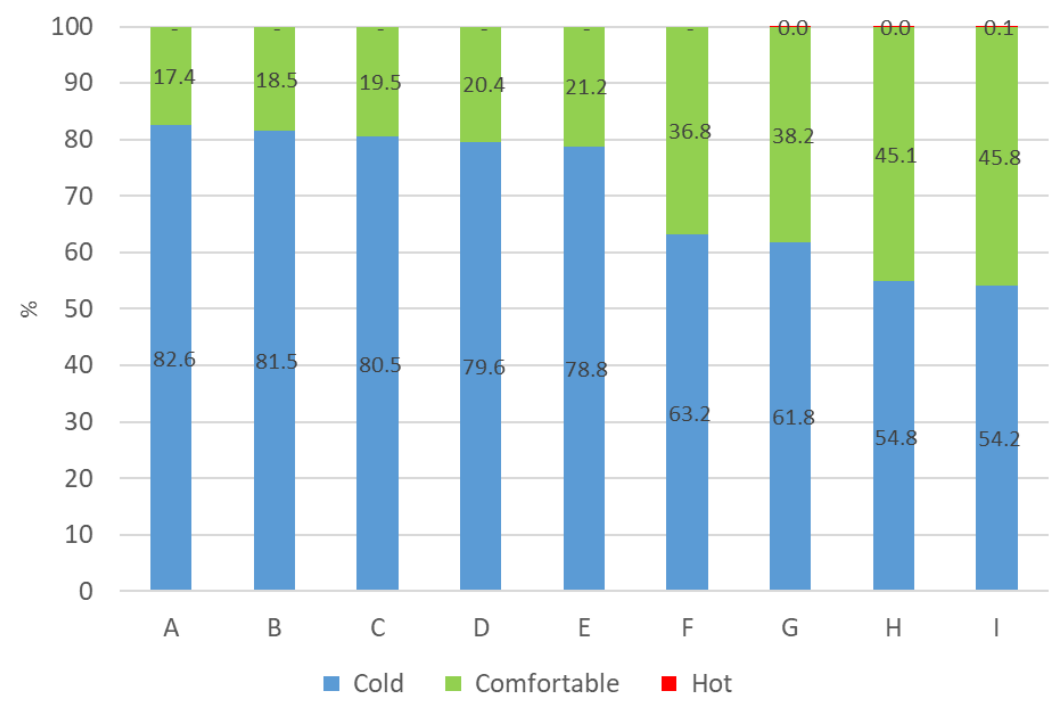

Figure 3. Results in percentage (\%) throughout $8760 \mathrm{~h}$ of the year of cold, comfortable and hot temperatures in each scenario according to the adaptive model of comfort.

Then the graphed carbon and cost life-cycle analyses (Figure 4) were presented and discussed with interviewees. The results for all scenarios were shown in tones of $\mathrm{kg} . \mathrm{CO}_{2}$ eq. for 90 years of carbon LCA (life cycle analysis) and in NZD (millions) for 20 years of cost LCA calculated as the NPV (net present value). A similar pattern to that shown for the thermal comfort analysis occurs with all assessment criteria-the whole insulation scenarios (F-I) show larger differences compared to single measure scenarios (B-E). The deep retrofit of all envelope components contributed to more than $50 \%$ savings in energy, carbon and costs over the 90 -year life-cycle, compared to a maximum $12 \%$ savings from single measures (e.g., walls or windows insulation).

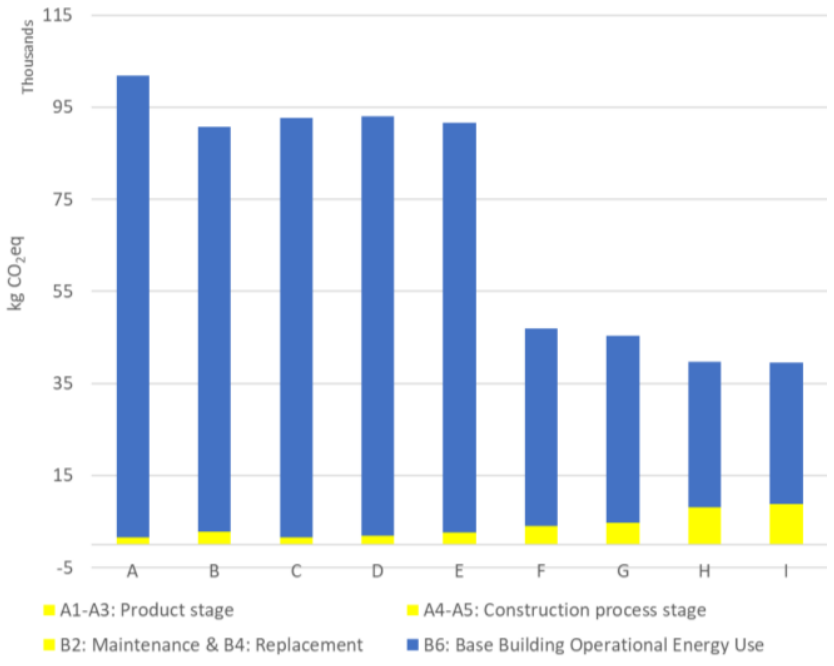

(a)

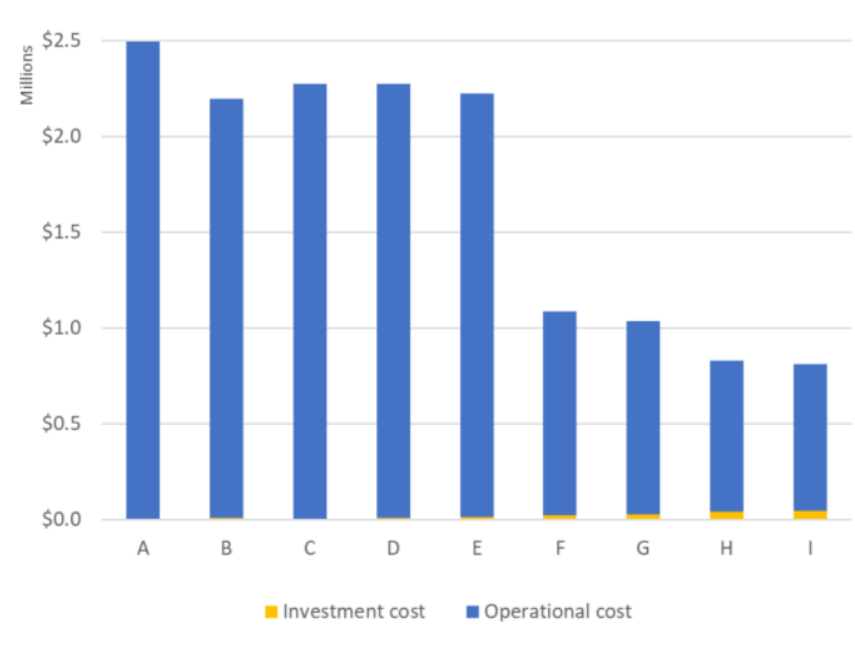

(b)

Figure 4. Embodied and operational carbon results (a) and investment and operational cost results (b).

The larger influence on operational costs of the deep retrofit compared to the operational carbon results can be explained by the shorter period of analysis of 20 years, hence less investment costs from material replacement. The embodied carbon and investment cost fraction within the LCA depend on the different materials' service-life. A sensitivity analysis was carried out by doubling the replacement cycles of all materials over 90-year 
lifespan. This showed the operational phase decreased from $78 \%$ to $65 \%$ of the total carbon footprint, reinforcing the importance when undertaking a life-cycle analysis of using the most accurate information for the chosen materials.

The graphs were discussed during the experts' interviews to explore how the LCA, investment cost and embodied carbon could influence their decision-making.

\section{Interviews Findings and Discussion}

The booklet was presented and discussed with each of the stakeholder experts during a one-hour individual, in-depth qualitative interview. Ten professionals from private and public organizations-five architects, one assets manager, one local government heritage advisor, one central government policy advisor, one urban planner, and one building services engineer were chosen through 'convenience and snow ball' sampling [55] as representative of the diverse stakeholders involved in a historic renovation $[8,11,33]$. Their selection was based on the different disciplines, background, level of professional experience and involvement in the heritage conservation sector. All had experience with historic conservation projects. The building is owned by the NZ public sector (the Wellington City Council), so the assets manager represented the ownership stakeholders. As the building has been unoccupied since 2018, occupants were not able to be interviewed.

The illustrated overview of the existing building and images of possible retrofit measures were provided first to the interviewee. They were then shown the model results as graphs (see Section 5), for thermal comfort, energy use, LCCA and LCC. Each was then asked a number of qualitative questions about the importance of applying the retrofit criteria and methods found in the international literature [10]; the practicality of adopting retrofit guidelines and appropriate methods; as well as challenges specific to NZ. The final questions investigated their thoughts on the heritage impact of the proposed retrofit measures and how conservation values influenced their decision-making.

\section{Summary of Findings}

The content from interviews was transcribed and grouped using thematic analysis, a widely-used qualitative method within psychology that reports on themes and also interprets different aspects of the research topic [56]. The content analysis, which was interpreted by triangulation with literature findings, identified four credible broad themes:

1. Experts' understanding of heritage impacts and possible trade-offs;

2. Links between the heritage assessments, the ICOMOS charters and principles,

3. Experts' knowledge of the multiple assessment criteria and methods, and

4. Main challenges before implementing guidelines through policy or practice.

Table 2 provides a summary of the main findings, with the four themes in the rows.

In terms of heritage impacts, retrofit Option F (whole house insulation with CWI R2.8) (see Table 1), which combined the CWI and double-glazing was considered by the experts as the preferred balanced solution for this building, offering the best cost-benefit with measures that would have an acceptable level of heritage impact. Despite moderate significance of the wall lining in the conservation plan [49], the experts considered that plasterboard was a 'modern material' compared to other historic fabric (e.g., external weatherboards), and therefore, an acceptable trade-off considering the broader outcomes of the house retrofit. Interviewee 2 said about the house, "Its character is no longer a 1900s cottage, plasterboard is a fair game because you have to change it out for modern that looks the same, hence all the trim still fit and you haven't really lost anything". However, there was no consensus on the impact of double-glazing, with some stakeholders preferring the less invasive, but still energy efficiency improving, option of draughtproofing and lined curtains. Interviewee 6 noted the final choice "is down to cost-if money is no object to double glazing. If money is a problem you draughtproof with curtains". 
Table 2. Summary of interview findings.

\begin{tabular}{|c|c|c|c|c|}
\hline \multirow[b]{2}{*}{$\begin{array}{l}\text { Heritage impact } \\
\text { assessment and } \\
\text { possible trade-offs }\end{array}$} & \multicolumn{4}{|c|}{ Main Findings } \\
\hline & $\begin{array}{c}\text { Preferred improving } \\
\text { whole house insulation } \\
\text { with reduced } \\
\text { airtightness (Option F) } \\
\text { due to cost-benefits and } \\
\text { lower heritage impact } \\
\text { compared to Options G, } \\
\text { H, and I. }\end{array}$ & $\begin{array}{l}\text { Internal wall insulation } \\
\text { solution raised } \\
\text { concerns about final } \\
\text { reduced footprint and } \\
\text { issues with } \\
\text { moisture control. }\end{array}$ & $\begin{array}{l}\text { Five out of ten experts } \\
\text { said that } \\
\text { double-glazing would } \\
\text { be reasonable and } \\
\text { would incur in small } \\
\text { modifications if costs } \\
\text { are not prohibitive. }\end{array}$ & $\begin{array}{l}\text { Trade-offs (e.g., loss of } \\
\text { existing plasterboard) } \\
\text { were acceptable for } \\
\text { broader } \\
\text { outcomes-improved } \\
\text { thermal comfort and } \\
\text { reduced carbon } \\
\text { emissions. }\end{array}$ \\
\hline $\begin{array}{l}\text { Conservation } \\
\text { principles }\end{array}$ & $\begin{array}{l}\text { Due to the preference } \\
\text { on CWI opposed to } \\
\text { IWI, the visual } \\
\text { appearance importance } \\
\text { was highlighted } \\
\text { compared to material } \\
\text { authenticity }\end{array}$ & $\begin{array}{l}\text { Existing plasterboard } \\
\text { trade-off was accepted } \\
\text { considering the overall } \\
\text { heritage significance } \\
\text { instead of single fabric } \\
\text { material significance. }\end{array}$ & $\begin{array}{l}\text { Some accepted } \\
\text { solutions are not } \\
\text { reversible but they } \\
\text { were accepted as long } \\
\text { as maintaining the } \\
\text { existing character } \\
\text { and appearance. }\end{array}$ & $\begin{array}{l}\text { Option F required less } \\
\text { intervention than } \\
\text { Options, G, H and I } \\
\text { according to } \\
\text { conservation experts, } \\
\text { following the principle } \\
\text { of minimum } \\
\text { intervention. }\end{array}$ \\
\hline $\begin{array}{l}\text { Assessment criteria } \\
\text { and methods }\end{array}$ & $\begin{array}{l}\text { Criteria and methods } \\
\text { used for this } \\
\text { investigation were } \\
\text { positively received and } \\
\text { approved by } \\
\text { all experts. }\end{array}$ & $\begin{array}{l}\text { Investment cost was } \\
\text { considered an } \\
\text { important aspect, } \\
\text { because the final results } \\
\text { for LCCA and LCC do } \\
\text { not duplicate when the } \\
\text { investment duplicates } \\
\text { (e.g., difference } \\
\text { between F and H } \\
\text { scenarios). }\end{array}$ & $\begin{array}{l}\text { Experts revealed that } \\
\text { looking on LCA results } \\
\text { "was really helpful" to } \\
\text { understand the scale of } \\
\text { differences between } \\
\text { embodied and } \\
\text { operational phases } \\
\text { influencing their } \\
\text { decision-making. }\end{array}$ & $\begin{array}{l}\text { The analysis of } \\
\text { embodied carbon of } \\
\text { insulation materials } \\
\text { could influence in } \\
\text { changes in the market } \\
\text { and in the use of low } \\
\text { embodied carbon } \\
\text { materials (e.g., more } \\
\text { use of wood fiber). }\end{array}$ \\
\hline $\begin{array}{l}\text { Challenges and } \\
\text { opportunities }\end{array}$ & $\begin{array}{l}\text { Public agencies (e.g., } \\
\text { HNZPT) could have } \\
\text { guidance documents as } \\
\text { many people use them } \\
\text { for advice. } \\
\text { All agreed that a } \\
\text { straightforward guide } \\
\text { with clear procedures } \\
\text { for required } \\
\text { assessments and } \\
\text { outcomes would be } \\
\text { very useful. }\end{array}$ & $\begin{array}{l}\text { Lack of practice on } \\
\text { secondary glazing } \\
\text { described by experts } \\
\text { confirmed the lack on } \\
\text { guidance material and } \\
\text { specific training. } \\
\text { Investment cost can be } \\
\text { a barrier in practice for } \\
\text { clients, landlords, } \\
\text { investors and even for } \\
\text { getting } \\
\text { resource consent. }\end{array}$ & $\begin{array}{c}\text { General lack of } \\
\text { understanding of use of } \\
\text { different ventilation } \\
\text { systems by users and } \\
\text { some professionals in } \\
\text { industry. } \\
\text { Weak understanding of } \\
\text { consequences and } \\
\text { effects of artificial } \\
\text { systems on the } \\
\text { building fabric. }\end{array}$ & $\begin{array}{c}\text { Barrier for introducing } \\
\text { new materials due to } \\
\text { compliance testing and } \\
\text { less demand in } \\
\text { industry. } \\
\text { Both historic } \\
\text { conservation and } \\
\text { building } \\
\text { performance-are } \\
\text { disconnected creating } \\
\text { an insecurity } \\
\text { environment. }\end{array}$ \\
\hline
\end{tabular}

The experts felt the broader outcomes achieved with the energy retrofit and the overall heritage significance assessment, instead of focusing solely on material authenticity may allow trade-offs and the use of measures that are not reversible. When considered with the test of authenticity recommended in the World Heritage Operational Guidelines (see Section 3), this may create possibilities beyond a simplistic physical and material focus. The interviews also revealed the main conservation points of concern were still related to visual, spatial and material impacts, aligning to EN 16883:2017 that looks at these three aspects together in order to assess the heritage significance impacts.

The existence of a CMP describing the historic house significance which was not limited to the architectural significance but also considered historic and social values, enabled this overall assessment. The existing overall authenticity of fabric gives opportunity for modifications, following the Burra Charter principles of "changing as much as necessary but as little as possible" with "appropriate use of modern techniques in some circumstances when there are substantial conservation benefits" [39]. In this case the benefits enabled the use of the house for over 100 years. In many similar NZ timber-frame houses, this solution may also be accepted, but all the conservation architects noted it is always a case-by-case 
analysis. This again stresses the importance of the CMP coverage in heritage significance assessment and renovation implementation.

For the last two themes identified in the interviews, all experts confirmed the relevance of international guidelines' assessment criteria, but added seismic requirements as an essential part of NZ assessments, as well as moisture checks. The lack of a hygrothermal analysis coupled with a deep energy retrofit (insulation, airtightness and ventilation levels) raised the experts' concerns of the compatibility of insulated components with existing fabric. Both European and American guidelines require a hygrothermal analysis as part of an assessment. However, when asked about different ventilation systems, there was uncertainty about the pros and cons of their use. Most of the conservation professionals would rely on natural ventilation in most rooms and extraction fans in bathrooms and kitchens.

As was expected, energy, carbon and LCC assessments are seldom applied in renovation projects in NZ and conservation architects have little or no experience with tools for energy and carbon analysis, and especially from the conservation practitioner's side there is a great concern on who to rely on specialized advice. Most of them considered that if carbon caps become mandatory for existing buildings, procedures and methods for calculation should be recommended for a standardization and comparison.

Ultimately, the experts felt that having specific guidelines for NZ showing clear procedures and methods for assessing proposed retrofit solutions would be of benefit, and that governmental agencies would be the best source for this kind of information because they are considered to be widely used, reliable sources. The experts also mentioned the Building Research Association of New Zealand (BRANZ) could be responsible for developing technical guidance on energy retrofit of historic buildings. NZ timber-frame constructions, unlike European historic timber-frame buildings which are often earth infilled, require different guidance information.

\section{Conclusions}

This case study of a theoretical retrofit of typical historic NZ timber-frame house, using mixed method of quantitative assessments and qualitative interviews, confirmed the lack of energy retrofit policies and practice. The interviews highlighted both the national and stakeholders' requirement for appropriate guidelines for renovation projects that deal both with conservation and technical aspects of typical constructions. All professionals agreed that adopting country-specific guidelines would benefit practice.

Despite the great interest expressed by the ten interviewed experts on adopting guidelines for energy retrofit, there was a concern from conservation professionals due to the New Zealand building sector's overall lack of knowledge of historic buildings' performance. The experts worried that some improvements may lead to future negative consequences, such as unforeseen moisture decay of existing fabric. For this reason, the experts also felt that regardless the existence of international documentation or guidance material, there was a need to test and experiment locally in order to have strong supporting evidence for proposed retrofit recommendations that would meet New Zealand's unique climatic, seismic, materials and construction issues. Therefore, beyond developing policies for historic buildings energy retrofit it would be of benefit having more examples (e.g., practice database) including pre- and post-retrofit monitoring results for energy use, air quality, temperature, humidity, hygrothermal properties of materials, etc., so as to build a better knowledge for the building sector, creating more confidence for everyday practice.

The experts unanimously agreed such analysis of balancing heritage values and energy upgrades will be shortly needed to meet increasing requirements for reduced GHG emission, but crucial gaps including a lack of skills and education in both the energy and building conservation fields need to be addressed. Life cycle analysis (LCA) will routinely become part of building construction and renovation assessments, as is already being proposed for new buildings. Therefore, both will need an extra level of skills training and appropriate research to address the many uncertainties and to reduce the current insecurity environment. 
Regarding heritage significance and LCA assessments, the findings show both assessments are essential in the decision-making process but have practical challenges though. The contribution of a comprehensive CMP is critical for heritage assessment, and it should be recommended as a method in guidelines. The renovation impacts should be compared with the list of significant values stated in the CMP, and in the case of historic places without a developed conservation plan the three aspects proposed in the EN 16883:2017 (e.g., material, visual and spatial impacts) should be assessed to mitigate highly impact solutions. Provisions regarding climate change and contemporary values such as sustainability should be in near future incorporated into reviews of CMP as a way of managing change, mitigating risks and facilitating the initial steps on the retrofit process. In addition, historic buildings without a CMP should have a significance assessment as a prior step.

The LCA was described as a beneficial assisting tool to promote better quality (e.g., low embodied carbon) and longer-lasting materials, as well as reducing investment cost barriers in the case of long-term benefits. The LCA graphs presented to interviewees were noted as helpful for decision-making; however, most of the professionals had little or no experience with these tools and methods. It would be of benefit if energy retrofit policies referred to country-specific indicative databases or simplified tools (e.g., including only significant phases for retrofits) to easily allow training and practice. Retrofit guidelines should reference standardized methods to allow comparisons for all assessment criteria (e.g., energy, carbon, cost, heritage significance), and more guidance and training in tools such as LCA, hygrothermal compatibility and heritage impact assessment will be required as they are the key instruments and opportunities to avoid inappropriate or wrong historic renovations decisions.

The results from assessments indicated that future policies for retrofitting historic buildings should consider the benefits from a deep retrofit approach, as compared to the smaller benefits from selecting only a single option. The deep retrofit analysis with measures such as envelope insulation, airtightness and ventilation systems should help avoid future (for example) moisture problems which are possible even with compatible materials.

It is also recommended that historic buildings should not be exempt from energy efficiency requirements, but policies should allow flexible targets, even if by little improvements. A key finding from a conservation perspective was that there is no one solution fits all as it is a case-by-case values-based assessment. However, energy retrofit guidelines from a policy and practice perspective are important to help achieving climate change targets and allowing good practice by avoiding simplistic choices of standard solutions, and possibly long-term risks being created.

Author Contributions: Conceptualization, R.P. and N.I.; methodology, R.P.; software, R.P.; validation, R.P. and N.I.; formal analysis, R.P.; investigation, R.P. and N.I; resources, R.P. and N.I.; data curation, N.I.; writing—original draft preparation, R.P.; writing—review and editing, R.P. and N.I; visualization, R.P.; supervision, N.I.; project administration, R.P. All authors have read and agreed to the published version of the manuscript.

Funding: This research received no external funding.

Institutional Review Board Statement: The study was approved by the Ethics Committee of Victoria University of Wellington (number 0000028088 and date of approval 14 August 2020).

Informed Consent Statement: Informed consent was obtained from all subjects involved in the study.

Data Availability Statement: Not applicable.

Acknowledgments: The authors would like to thank the support from the Victoria Doctoral Scholarship, all interviewed professionals and Wellington City Council.

Conflicts of Interest: The authors declare no conflict of interest. 


\section{References}

1. United Nations Environment Programme. Buildings and Climate Change: Current Status, Challenges and Opportunities; UNEP: Nairobi, Kenya, 2007.

2. Barros, V.R.; Field, C.B. Climate Change 2014: Impacts, Adaptation, and Vulnerability: Part B: Regional Aspects; Cambridge University Press: Cambridge, UK, 2014.

3. Hosagrahar, J.; Soule, J.; Potts, A.; Girard, L. Cultural Heritage, the UN Sustainable Development Goals, and the New Urban Agenda. Bolletino Cent. Calza Bini 2015, 16, 1.

4. Webb, A.L. Energy Retrofits in Historic and Traditional Buildings: A Review of Problems and Methods. Renew. Sustain. Energy Rev. 2017, 77, 748-759. [CrossRef]

5. Troi, A.; Bastian, Z. Energy Efficiency Solutions for Historic Buildings: A Handbook; De Gruyter: Berlin, Germany, 2015.

6. May, N.; Griffiths, N. Planning Responsible Retrofit of Traditional Buildings; Sustainable Traditional Building Alliance: London, UK, 2015; Volume 24.

7. Martínez-Molina, A.; Tort-Ausina, I.; Cho, S.; Vivancos, J.-L. Energy Efficiency and Thermal Comfort in Historic Buildings: A Review. Renew. Sustain. Energy Rev. 2016, 61, 70-85. [CrossRef]

8. CEN EN 16883:2017. Conservation of Cultural Heritage-Guidelines for Improving the Energy Performance of Historic Buildings; CEN: Brussels, Belgium, 2017.

9. ASHRAE. ASHRAE Guideline 34P, Energy Guideline for Historical Buildings; ASHRAE: Peachtree Corners, GA, USA, 2019.

10. Paschoalin, R.; Isaacs, N. Holistic Renovation of Historic and Heritage Buildings: Comparing New Zealand and International Scenarios. Int. J. Build. Pathol. Adapt. 2020. ahead of print. [CrossRef]

11. Herrera-Avellanosa, D.; Haas, F.; Leijonhufvud, G.; Brostrom, T.; Buda, A.; Pracchi, V.; Webb, A.L.; Hüttler, W.; Troi, A. Deep Renovation of Historic Buildings: The IEA-SHC Task 59 Path towards the Lowest Possible Energy Demand and $\mathrm{CO}_{2}$ Emissions. IJBPA 2019, 38, 539-553. [CrossRef]

12. UN. The Sustainable Development Goals Report 2017; United Nations: New York, NY, USA, 2017; p. 60.

13. English Heritage. Energy Efficiency and Historic Buildings-Application of Part L of the Building Regulations to Historic and Traditionally Constructed Buildings; Historic England: London, UK, 2012.

14. Heritage Victoria. Heritage Buildings and Sustainability; Heritage Victoria: East Melbourne, VIC, Australia, 2009.

15. Heritage Victoria. Heritage Buildings and Energy Efficiency Regulations; Heritage Victoria: East Melbourne, VIC, Australia, 2009.

16. Lidelöw, S.; Örn, T.; Luciani, A.; Rizzo, A. Energy-Efficiency Measures for Heritage Buildings: A Literature Review. Sustain. Cities Soc. 2019, 45, 231-242. [CrossRef]

17. Buda, A.; de Place Hansen, E.J.; Rieser, A.; Giancola, E.; Pracchi, V.N.; Mauri, S.; Marincioni, V.; Gori, V.; Fouseki, K.; Polo López, C.S.; et al. Conservation-Compatible Retrofit Solutions in Historic Buildings: An Integrated Approach. Sustainability 2021, 13, 2927. [CrossRef]

18. Aigwi, I.E.; Egbelakin, T.; Ingham, J. Efficacy of Adaptive Reuse for the Redevelopment of Underutilised Historical Buildings: Towards the Regeneration of New Zealand's Provincial Town Centres. Int. J. Build. Pathol. Adapt. 2018, 36, 385-407. [CrossRef]

19. Ministry of Business, Innovation, and Employment Building (Earthquake-Prone Buildings) Amendment Act 2016. NZ 2016. Available online: https://www.legislation.govt.nz/act/public/2016/0022/latest/DLM5616102.html. (accessed on 10 February 2021).

20. Ministry of Environment Understanding Our Emissions Reduction Targets. NZ; 2018. Available online: http://www. mfe.govt.nz/climate-change/what-government-doing/emissionsreduction-targets/understanding-our-target (accessed on 9 September 2020).

21. New Zealand Government Climate Change Response (Zero Carbon) Amendment Act 2019. 2019. Available online: http: / / www.legislation.govt.nz/act/public/2019/0061/latest/LMS183736.html (accessed on 17 November 2020).

22. Ministry of Business, Innovation \& Employment New Zealand Building Code-Clause H1 Energy Efficiency 2017. Available online: https://www.building.govt.nz/building-code-compliance/h-energy-efficiency/h1-energy-efficiency (accessed on 9 September 2020).

23. New Zealand Government Residential Tenancies (Smoke Alarms and Insulation) Regulations 2016. 2016. Available online: https:/ / www.legislation.govt.nz/regulation/public/2016/0128/16.0/DLM6856201.html (accessed on 9 September 2020).

24. Kohler, A. Unhealthy Living. Available online: https://architecturenow.co.nz/articles/unhealthy-living/ (accessed on 27 April 2021).

25. Wolfe, R. New Zealand's Lost Heritage: The Stories behind Our Forgotten Landmarks; New Holland: Auckland, New Zealand, 2013.

26. Radio New Zealand. Wellington Housing: Council Considers Protecting More "Character" Areas. Available online: https: / / www.rnz.co.nz/news/national/444949/wellington-housing-council-considers-protecting-more-character-areas (accessed on 27 April 2021).

27. Wellington City Council. Our City Tomorrow-Draft Spatial Plan for Wellington City; Wellington City Council: Wellington, New Zealand, 2020.

28. Hockley, A. Progress and the Past: Getting the Spatial Plan Right the First Time. Dominion Post. 2020. Available online: https:// www.stuff.co.nz/dominion-post/comment/123159728/progress-and-the-past-getting-the-spatial-plan-right-the-first-time (accessed on 14 August 2021).

29. Carbonara, G. Energy Efficiency as a Protection Tool. Energy Build. 2015, 95, 9-12. [CrossRef] 
30. Besen, P.; Boarin, P. The future of historic buildings: Retrofitting to improve the thermal performance of New Zealand architectural heritage. WIT Trans. Ecol. Environ. 2018, 217, 15-27.

31. BRANZ Renovate-The Technical Resource for Industry. 2011. Available online: https://www.renovate.org.nz/ (accessed on 9 September 2019).

32. Buckett, N.; Burgess, J. Real Experience of Retrofitting for Sustainability; BRANZ: Auckland, New Zealand, 2007 ; p. 12.

33. Kamari, A.; Corrao, R.; Kirkegaard, P.H. Sustainability Focused Decision-Making in Building Renovation. Int. J. Sustain. Built Environ. 2017, 6, 330-350. [CrossRef]

34. De Santoli, L. Guidelines on Energy Efficiency of Cultural Heritage. Energy Build. 2015, 86, 534-540. [CrossRef]

35. De Santoli, L.; Bellia, L.; Corgnati, S.P.; Ambrosio, F.R.; Filippi, M.; Mazzarella, L.; Romagnoni, P.; Sciurpi, F. Efficienza Energetica Negli Edifi Storici; Editioriale Delfino srl: Milano, Italy, 2014; ISBN 978-88-97323-26-6.

36. Araoz, G. Conservation Philosophy and Its Development: Changing Understandings of Authenticity and Significance. Herit. Soc. 2013, 6, 144-154. [CrossRef]

37. Stovel, H. Origins and Influence of the Nara Document on Authenticity. APT Bull. J. Preserv. Technol. $2008,39,9-17$.

38. ICOMOS. International Charter for the Conservation and Restoration of Monuments and Sites (The Venice Charter 1964). Available online: https:/ / www.icomos.org/charters/venice_e.pdf (accessed on 12 September 2019).

39. ICOMOS Australia. The Burra Charter: The Australia ICOMOS Charter for Places of Cultural Significance; ICOMOS: Melbourne, Australia, 2013.

40. ICOMOS. The Nara Document on Authenticity 1994. Available online: https:/ /www.icomos.org/charters/nara-e.pdf (accessed on 12 September 2019).

41. Jokilehto, J. Considerations on authenticity and integrity in world heritage context. City Time 2006, 2, 16.

42. ICOMOS NZ. ICOMOS New Zealand Charter for the Conservation of Places of Cultural Heritage Value; ICOMOS: Auckland, New Zealand, 2010.

43. Wellington City Council. Wellington Heritage Policy; Wellington City Council: Wellington, New Zealand, 2010.

44. Worthing, D.; Organ, S. Conservation Management Plans: An Examination of Obstacles to, and Opportunities for, Producing an Effective Management Tool. IJBPA 2019, 38, 573-588. [CrossRef]

45. Onecha, B.; Dotor, A.; Marmolejo-Duarte, C. Beyond Cultural and Historic Values, Sustainability as a New Kind of Value for Historic Buildings. Sustainability 2021, 13, 8248. [CrossRef]

46. Wijesuriya, G.; Thompson, J.; Young, C. Managing Cultural World Heritage; UNESCO World Heritage Centre: Paris, France, 2013; ISBN 978-92-3-001223-6.

47. Isaacs, N. Dry Under the Floor: Development of NZ House Sub-Floor Ventilation Requirements. In Back to the Future: The Next 50 Years; Architectural Science Association: Auckland, New Zealand, 2017; pp. 497-507.

48. Arden, S.; Bowman, I. The New Zealand Period House: A Conservation Guide; Random House: Auckland, New Zealand, 2004.

49. Murray, R.; Kelly, M. Former Custodian's Residence-86 Clark Street; Wellington City Council: Wellington, New Zealand, 2005.

50. Wellington City Council. Historic House Needs New Lease of Life. Available online: https:/ /wellington.govt.nz/news-andevents/news-and-information/our-wellington/2018/06/historic-homestead-roi (accessed on 14 July 2021).

51. Environmental Health Indicators. New Zealand. Available online: https://www.ehinz.ac.nz/indicators/indoor-environment/ about-the-indoor-environment-and-health/\#cold-and-damp-houses-and-health (accessed on 7 April 2021).

52. Donn, M.; Thomas, G. Designing Comfortable Homes. Guidelines on the Use of Glass, Mass and Insulation for Energy Efficiency, 2nd ed.; CCANZ: Wellington, New Zealand, 2004.

53. ASHRAE. ANSI/ASHRAE Standard 55-2013, Thermal Environmental Conditions for Human Occupancy; ASHRAE: Peachtree Corners, GA, USA, 2013.

54. Sassine, E.; Kinab, E.; Cherif, Y.; Antczak, E.; Nasrallah, M. Thermal Performance of Lightweight Concrete Applications in Building Envelopes in Lebanon. Build. Simul. 2021, 14, 1359-1375. [CrossRef]

55. Lewis-Beck, M.; Bryman, A.; Futing Liao, T. The SAGE Encyclopedia of Social Science Research Methods; SAGE: Thousand Oaks, CA, USA, 2004. [CrossRef]

56. Braun, V.; Clarke, V. Using Thematic Analysis in Psychology. Qual. Res. Psychol. 2006, 3, 77-101. [CrossRef] 